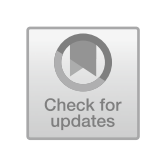

\title{
Introduction: The Pirate as a Figure of Crisis and Legitimacy
}

Pirates are everywhere today. Over the last decade, there have been numerous reports of Somali and new Caribbean 'piracy' in the news; data 'pirates' are persecuted by the defendants of copyright law and intellectual property; eco-activist groups on the high seas, often on the border of transgressing laws that protect global corporate business rather than oceanic ecosystems, are termed pirates in the media while they themselves have also adopted piratical symbols like the skull and crossbones. Similarly, "Pirate Parties" throughout Europe, though perhaps past their heyday, have used the label to question the future of representative democracy in favor of more direct forms of government. In popular cultural contexts, pirate symbols are used by the fashion and many other industries and, since Disney's Pirates of the Caribbean series and a number of piratethemed computer games, have become prominent figures on the screen again. All of these examples actively draw on the figure of the pirate and its ambiguous semiotic qualities as a symbol used for both Othering and identification.

In an Anglophone Atlantic context, it is between the colonial era and the mid-nineteenth century that pirates emerged as prominent figures. In prose writing alone, the popular cultural, sensational appeal of pirateinspired adventure stories, captivity narratives, popular histories and romances, and many other genres-in-the-making, was used in terms of the figure's potential to articulate moments of ontological instability and

A. Ganser, Crisis and Legitimacy in Atlantic American Narratives of Piracy, Maritime Literature and Culture, https://doi.org/10.1007/978-3-030-43623-0_1 
epistemological crisis through an adequate ambivalent trope. ${ }^{1}$ The present study critically examines literary renditions of the pirate from 1678, the publication year of the earliest and probably most widely known booklength pirate narrative, A. O. Exquemelin's Buccaneers of America, to the American Civil War, when the pirate figure was used in battling the legitimacy of Southern Secession. Prose narratives of piracy were significant for the formation and development of a number of popular genres in print culture across the Atlantic: published trial reports, gallows narratives, execution sermons, broadsides, and criminal biographies in the late seventeenth and early eighteenth centuries, in which condemned pirates occasionally found an opportunity to justify their actions; popular history and the historical romance in the eighteenth and nineteenth centuries, which romanticized the pirate as a revolutionary outlaw; the captivity narrative during the so-called U.S. 'Barbary Wars' against North African city-states (1801-1805, 1815), in which former American captives of Muslim 'pirates' in the Mediterranean who were sold into slavery compared these corsairs to the triangular slave-traders; or caricatures of Southern 'pirates' at the beginning of the Civil War, which were printed on Union envelopes to deplore Secession.

The etymological source of the word "piracy," the Greek verb peiran (to attempt, attack, from the root per-, which literally means "to attempt something"), refers to ventures into risky business or the unknown, activities which characterized Mediterranean marauders in classical antiquity who became known as pirates (Rennie 2013, 11). Historians often characterize pirates by their shifting, and hence unreliable, national, racial/ethnic, and at times even gender affiliations (e.g., Rediker 2004; Creighton and Norling 1996) - the main reason why they have vexed political theorists and legal scholars for centuries in their attempts to define the pirate's legal status and his/her illegitimacy. Disputes about who was to be called pirate have always articulated power relationships and struggles over authority and legitimate violence, as the famous anecdote of the pirate and the emperor, related in St. Augustine's City of God, illustrates: "For elegant and excellent was the pirate's answer to the great Macedonian Alexander, who had taken him: the king asking him how he durst molest the sea so, he replied with a free spirit, 'How darest thou molest the whole world? But because I do with a little ship only, I am called a thief: thou doing it with a great navy, art called an emperor"' (Book IV, quoted in Pérotin-Dumon 1991, 196). ${ }^{2}$ Taking up related questions raised by various strands of pirate scholarship (e.g., 
Rennie 2013; Schillings 2017), I explore the pirate's primary discursive function as that of a personified question about legitimacy in diverse critical contexts. Throughout this book, I am asking in what ways a transoceanic American cultural imaginary teased out the pirate's ambivalent potential as a figure of identification and Othering, as outlaw folk hero and deplorable criminal, to negotiate scenarios of legitimacy and crisis in Anglophone North America. ${ }^{3}$

Because of their semantic ambiguity and the elusiveness of their identity, pirates have defied normative regimes of representation; as a literary trope, piracy has allowed for a symbolic (re-)negotiation of various identity constructions (such as British colony versus independent Republic; or united versus divided, free or slaveholding States during the War of Secession). My study inquires into ways in which narratives of piracy articulate, on both the textual and the meta-textual levels, oppositional discursive positions regarding questions of legitimacy, using piracy's destabilizing potential with regard to constructions of racial, ethnic, and gender difference. I argue that narratives of piracy continuously and dynamically swerve between dominant and resistant cultural positions, between, for instance, resistance to the Atlantic slave trade and participation in it; or between the subversion and affirmation of normative gender roles. In addition, narratives of piracy frequently turned the pirate from an agent of disruption, questioning the social order, into a figure of affirmation and containment. ${ }^{4}$ This study hence casts piracy as a discursive category on a continuum between the propagation of colonial adventure and accumulation on the one hand and critical commentary on exploitation, colonial violence, and racialized, gendered, and class oppression on the other. This dismantles the mythology of piracy as either leftist, anarchic utopia (e.g., Bey; Kuhn; Wilson) or capitalist avant-garde (e.g., Leeson, Storr)—one of the main oppositions critics have relied on in various conceptualizations of the pirate. In what follows, pirates appear as repentant sinners on the verge of execution; as defiant rebels against colonial authorities; as crafty tradesmen whose aim is profit and gain, but also as fast and excessive spenders; as radical philosophers and religious dissenters; as slave-holders and as liberators of slaves; as cartographers, scientists, and picaresque traveler-adventurers on the margins of empire; as atrocious and as egalitarian masters; and as multinational proponents of an alternative order. 
One of my main hypotheses is that pirate narratives articulate a Freudian return of the repressed-of colonial violence and resistancein critical moments of North American history. Defined by maritime theft and illegitimacy, the pirate figure represents the "specter of slavery" and "the phantom of luxury," as David Shields labels the two crucial hauntings of colonialism (and later imperialism) in the Americas in reference to the British imperium pelagi ('empire of the seas,' 1990, 18). I aim to show that textual economies of piracy, despite their narrative resistance to a race-, class- and increasingly nation-based Atlantic order, are always already undermined by the enslavement and exploitation of indigenous and African/Afrodiasporic populations as well as by the triangular trade increasingly encompassing the entire Atlantic world in the late seventeenth and eighteenth centuries.

Literary and cultural studies of piracy by scholars such as Gesa Mackenthun, Nina Gerassi-Navarro, or Paul Baepler-to name but a few-have explored the narratives forming the basis of most theories of piracy, contributing significantly to the current state of piracy research and enabling us to see piracy as a complex phenomenon that cannot be contained within either a Marxist or a free-market grand narrative. Instead, the figure of the pirate is informed by both its implication in colonial political economies and its dissociation from, even scorn of, dominant colonial practice. The plethora of Anglo-American texts on piracy from the late seventeenth until the mid-nineteenth centuries dismantles any 'either/or' preconceptions in the characterization of piracy. In any case, pirates appear as textual constructions recalling historical agents that provoked colonial authorities in a multipolar (post-)colonial Atlantic world to write back, to contain the pirate: to turn him (and to a much lesser extent her) from an agent of disruption, questioning the social order, into a figure of affirmation.

The simplistic opposition between pirates as figures either of a colonial avant-garde or of resistance will be complicated by a close analysis of a variety of pirate narratives. My study introduces pirates as figures symptomatic of intense ontological and epistemological periods of crisis, in which perpetual struggles over (cultural, legal, political, economic) categorization and meaning were more intensely debated than at other times and intermittently resolved - in one direction or another-by a plethora of cultural narratives. These texts tease out the complexity of piracy as a cultural and economic phenomenon as well as the many contradictions at the heart of the fledgling merchant empires and their slave 
economies. Voicing both critique and complicity, pirate narratives and images, I am arguing, functioned as seismographs for the turmoil and upheavals produced by this trans-Atlantic and increasingly trans-Pacific economy. Located at the intersections of Atlantic American and hemispheric studies, (post-)colonial studies, and a New Historicist approach that reads texts from the angle of their historical-cultural context while viewing literature itself as productive of this very context, this book sets out to explore the pirate's popular appeal in Anglophone America from a transatlantic angle, taking into account the figure's history of translation from Europe to the Americas and focusing on the function of pirate narratives and the "cultural work" (Tompkins 1985) these texts perform.

In the context of historical crisis scenarios (see below), the figure of the pirate raises questions about the stability and legitimacy of (legal, political, cultural) categorization. I ask in what ways narratives of piracy act as manifestations of a perceived crisis and analyze the pirate in popular narratives as negotiating interlocking ideas of legitimacy not only due to the figure's ambivalent discursive position but also because the term "pirate" itself evokes a categorical putting-at-risk of self and society. Reading narratives of piracy as symptomatic of categorical crisis, I explore in what ways the pirate was imbued with (de)legitimatory meaning in the context of historical crisis scenarios, both in canonical and popular literature, which each interpellated their readerships to reflect on pressing issues of legitimacy.

The oceanic element in definitions of piracy has traditionally contributed an element of wilderness (as historically opposed to civilization) that has been crucial for various political and juridical debates over piracy and its definition, in which legitimacy has always been decisive: "The binary opposition between the pirate and civilization is ... manifested by an actor who represents piracy and a state which represents civilization" and "civilized order" (Schillings 2011, 297; also 2017 for a more detailed analysis). Consequently, the pirate has been imagined as lacking allegiance with any state, as "a fragment of the sea, i.e. the ungovernable wilderness" (297). Piracy's oceanic setting, defined by "exceptional legal rules" (Heller-Roazen 2009, 10), has invited the proclamation of a state of exception that legitimizes the reduction of political subjects to "bare life." Civil rights and other norms are fully suspended (though not abandoned) and exceptional measures are taken, as Giorgio Agamben explores in his work on biopolitics and Western political thinking's definition of sovereignty as power over life. The state of exception, Agamben explains, "is neither external nor internal to 
the juridical order, and the problem of defining it concerns precisely a threshold, or a zone of indifference, where inside and outside do not exclude each other but rather blur with each other" $(2005,23)$. Defined in such a relation of exception, the pirate is included in the legal order only by her/his exclusion through the sovereign (1998, 18). Conceptualizing exception as a "limit figure" that embodies the "radical crisis" at the heart of legitimacy and political authority (24-25), Agamben highlights its ambiguity as a 'both/and' concept that cannot be made to denote one thing or the other (here: inside or outside). ${ }^{5}$ The operation of sovereignty-the inclusion of subjects that essentially defy categorical insertion into a binary order by the claim to an exception-thus produces "bare life" as its originary activity (83).

Since classical antiquity, maritime pirates have been contrasted with land-based thieves because of their greater motility (i.e., capability of movement) and the sea allowing for a more rapid escape: ${ }^{6}$ piracy negated territorial and political borders, operating from spaces which were initially beyond the claims of states and empires (Beasley-Murray 2005, 220, 222). In the mobile world of the various Atlantic migrations, from the Puritan Great Migration to the triangular slave trade and nineteenthcentury immigration, the figure of the pirate encompasses traits of all the major characters of that mobile world: the trader, the adventurer, the pilgrim, the slave, and the indentured laborer as well as the slaveholder and-trader. In historical and literary discussions of piracy, major anxieties about an increasingly mobile society were voiced. Discourses about legitimate and illegitimate mobility appear as a defining aspect in pirate narratives, as piratical mobilities have been cast as both a threat to and as supportive of European colonial expansion and the imperialist project. The menace of uncontrollable geographical and social mobility that pirates signified was therefore closely related to social mobility and discontent with one's inherited class position. In the early modern era, just as control over people's mobility was increasingly nationalized (Cresswell 2006, 12-13), pirates emerged as emblematic of another new world: "the world of Hobbes, Galileo, and Harvey, ... an infinite, restless entanglement of persistent movement" in which "happiness itself was based on the freedom to move" (14). Piracy narratives articulated this emergent world, a world full of colonial dreams and nightmare realities. Ships and the sea, coasts and islands are main settings of this literature, which 
presents them as paradoxical spaces in which the dream and the nightmare are articulated in conjunction-as conflicted imperial and resistant sites and as fluid, permeable spaces of conflict and struggle, all the more so because ships and the coasts and islands they populated signified major stages of cultural contact and encounter. Because of their central position in the colonial economy in general and for slavery in particular, pirate ships became a popular literary topos, especially for writers critiquing slavery (see Sect. 3.1). As such, the ship and the sea emerge as the main textual spaces in which hegemonic and anti-hegemonic mobilities take effect. ${ }^{7}$ The double nature of the pirate ship, mirroring colonial relations while simultaneously inverting them in critical moments, can be read as a Foucauldian (1986) heterotopia of the crisis of colonial legality and of deviation: a site outlawed by a dominant order that labels it piratical, thus placing the enslaved or otherwise colonized subject, whose economic and military actions are unsanctioned, into a realm of illegitimacy and disenfranchisement. Unlike the prison, however, the pirate ship can function as a mobile inversion of dominant social relations and hence is also a site of social experimentation and potential empowerment-arguably the reason why it represented an attractive setting for revolutionary or abolitionist writers.

Salvatore Poier summarizes that "the status of 'pirate' is not related to a specific set of activities that are, in and of themselves, 'criminal' as "this category took shape through the relationships with those who were labelled 'pirates,' the constituted power, the mob, and the future of a newly discovered territory" $(2009,39)$ such as America. The postclassical, modern development of the category of piracy is thus intricately tied to a liminal geography of American coloniality. Especially in the discourse of international law, the pirate emerged as a foil for the integration of European nation-states, which tried to project the law of the land, a territorial order, onto maritime spaces (Heller-Roazen 2009, 100-101). Yet what is at stake in critical discussions of piracy is clearly not just legalistic description-after all, as Anne Pérotin-Dumon reminds us, "there is not, and never has been, an authoritative definition of piracy in international law"- but also the analysis of "what authority made the laws" and "what power was at stake" $(1991,198)$ in definitions-and representations, as I am arguing-of maritime piracy. Jon Beasley-Murray suggests that the historical legal construction of piracy as Other obfuscates that "[p]iracy cannot be simply demarcated as a constituent exterior to the civilized state" as "[ $\mathrm{t}]$ he pirate is not the colonial other; the pirate inhabits 
and crosses the permeable membrane that divides enemy from foe, civilization from its other" $(2005,224)$. In the aftermath of sixteenthand seventeenth-century debates over law-making, power, warfare, and violence, especially with regard to the seas and whether they were to be mare clausum or mare liberum (Pérotin-Dumon 1991, 205; Thomson 1994, ch. 4 \& 5; Heller-Roazen 2009, ch. 11), early eighteenth-century images of the pirate increasingly drew on a lack of national and ethnic character and an alleged non-humanity. Pirates were at times represented as cruel, subhuman, cannibalistic Others on a continuum with the 'Indian' or 'savage'; a monstrous, uncivilized, animal-like creature and a parasite (Kempe 2010, 160, 263) that threatened the translatio imperii et studii once he left his assigned role of privateer or military aid in national endeavors (Kempe 2008, 397). Indeed, as Schillings remarks, the difference between pirate and privateer marks a threshold between "the inside and the outside of the law" which "renders certain forms of reference to sovereignty by violent actors ... potentially legitimate to the sovereign, and therefore worthy of re-inclusion in the law" (2015, 31). Along similar reasoning, western states also framed non-Christian sea actions as piracy, such as in the so-called Barbary conflicts of the seventeenth and eighteenth centuries (Pérotin-Dumon 1991, 213). When non-state, allegedly uncivilized and/or indigenous agents that cooperated with each other diverged from the course of a state-controlled imperialism (and, for instance, started building alternative social communities), legal and political theorists and decision-makers sought to delegitimize such endeavors.

Following Pérotin-Dumon and others, I interpret the pirate's primary discursive function as that of a personified question about legitimacy (304)-hence the pirate's discursive ambivalence between 'good' and 'bad,' folk-hero and criminal, Othering and identification. This ambivalence also marks the figure of the pirate as more than well suited for a leading role in narrative negotiations of various scenarios of crisis. Historically, piracy has led states to take exceptional measures from the seventeenth to the nineteenth centuries. Such measures are, in Agamben's view, always results of (what is constructed and represented as) political crisis $(2005,1)$. The semantic category of piracy, defined by its legal and spatial exceptionality, has indeed been mobilized most frequently in times of crisis-cultural-symbolic, political (foreign and domestic), economic, and social. Of course, crisis is not factual, but is itself a narrative construction, produced by a discursive environment that frames individual or 
collective perceptions of crisis (Fenske et al. 2017; Grunwald and Pfister 2007). Sociologists and political scientists have theorized crisis using various approaches, most notably Marxist (in reference to the repeated crises of capitalism discussed by Gramsci; see Jones 2006, ch. 7) and governmental ones. ${ }^{8}$ The concept of crisis, from the Greek verb krinein ("to select and judge, to decide, struggle," Koselleck 1978, 617), has been used in different contexts, all of them referencing a point in which an existential decision, such as that between an old order or a new one, needs to be made. The problematic of crisis as a dualistic concept (between justice and injustice, or freedom and slavery, for instance) has been countered by Goethe's notion of crisis as a process and as transformation (624) as well as by the inclusion of what Reinhart Koselleck, in his classical 1982 summary of the conceptual development of crisis, has termed "possibilities crossing dualistic conceptions of crisis" ("quer [zur dualistischen Krise] verlaufenden Möglichkeiten," 626; my translation). Crisis, in Koselleck's understanding, implies a transformation of difference categories and of loyalties (630); it entails "transdifferent" (Breinig and Lösch) moments of semantic and symbolic instability. ${ }^{9}$ In any case, the diagnosis of crisis, he argues, has always served as a "title of legitimation for political action" (625: "Legitimationstitel politischen Handelns," my translation). This makes the nexus of crisis and legitimacy a highly productive categorical point of departure and frame of inquiry for the present study.

As Ansgar Nünning and others argue, narrative is central to the construction (and resolution) of scenarios of crisis, as crises constitute "medial transformations and (re-)presentations of situations in specific stories and narratives" ("mediale Transformationen und [Re-]Präsentationen von Geschehen in bestimmten Geschichten und Erzählungen," my translation): "Thus crises are observable in literary and cultural studies only in their textual and medial manifestations, i.e. in the discursive presentation of a particular story as a narrative of crisis" ("Literatur- und kulturwissenschaftlich beobachtbar sind Krisen somit erst in ihren textuellen bzw. medialen Manifestationen, d.h. in der diskursiven Präsentation dieser bestimmten Geschichte als Krisenerzählung," Nünning 2007, 61, my translation; see also Nünning 2009). Similarly, Stuart Hall suggested that in times of greatest crisis, the manufacture and manipulation of public consent is crucial to the maintenance of power: " $[\mathrm{M}]$ oments in which the equilibrium of consent is disturbed, or where the contending class forces are so nearly balanced that neither can achieve 
that sway from which a resolution to the crisis can be promulgated, are moments when the whole basis of political leadership and cultural authority becomes exposed and contested" (quoted in Davis 2004, 111). In what ways do narratives of piracy expose, and at times contest, such cultural-symbolic structures, and how do they act as manifestations and negotiations of crisis? These are the primary questions discussed in my readings.

In my study, I am not myself diagnosing historical moments from the seventeenth to the nineteenth century as marked by crisis, but rather look at periods that have been perceived and analyzed as such in both contemporaneous and historical accounts. The 'discovery' of America, for instance, was characterized as a pivotal crisis for the political system of Europe (Koselleck 1978, 634, 639), resulting, in the seventeenth century, in a "foundational" (82) "crisis of legitimation, an overlapping set of political crises, involving religious and civil wars, and international conflict" (Kahn 2002, 67). The epistemological crisis concerning the establishment and maintenance of difference categories at the basis of western knowledge-production was triggered by the scientific revolution and the simultaneous contact with America: beginning with Columbus' letters, many reported wonders had to be integrated into existing symbolic orders and emergent western systems of knowledge/power (Foucault); the quantity and quality of sensational news from faraway corners of the globe provoked a crisis of the concepts of truth and authority as well as of the cultural meaning of testimony and witnessing. This crisis was answered symbolically by the transformation of the pirate into a colonial agent and scientist before and around 1700, which I examine in the opening chapter. This period was also a time of crisis in colonial relations: when colonized groups turned against their colonizers and started to collaborate, both politically and economically, with illegitimate agents such as pirates or smugglers, as was the case at the end of the seventeenth century, piracy became an important literary topos. I begin with an analysis of A. O. Exquemelin's Buccaneers of America, reading the text's staging of cultural encounter as reflective of these crises. The text inspired a series of ethnographic narratives about the New World by former 'pirates' at the close of the seventeenth century (e.g., William Dampier, Basil Ringrose, Bartholomew Sharp, and Lionel Wafer), written as evidence of their authors' gradual transformation into scientists (which I compare to Exquemelin's): they adopted a discourse of science and 
helped legitimize colonial plunder-material and symbolic-as beneficial to the European "empire of knowledge."

The second part of that chapter moves, together with historical pirates, from the Caribbean to the coasts of New England in the early eighteenth century. It focuses on Puritan anti-piratical sermons and gallows narratives which prominently articulated piracy in the late seventeenth and early eighteenth centuries as sinful, devilish, and destructive for the community. In fact, the condemnation of piracy served to consolidate the society of third-generation Puritans, many of whom saw the increasing secularization of a theocratic society and the colony's socioeconomic developments as a threat to their covenant with God. This crisis was not only of a religious kind; in the Puritan understanding, the concept of crisis had distinct medical connotations and related to existential questions of survival or death. Thus, public executions of pirates and the sermons and broadsides produced for these events used the figure of the pirate as an Other against whom to renew social cohesion. In this sense, I read Cotton Mather's and other Puritan comments on piracy as a second discursive moment around 1700 responding to the perception of a collective crisis.

In Chapter 2, I explore the trope of piracy as it was summoned in the context of the (post-)revolutionary Atlantic that culminated in the crisis of colonial legitimacy in the North American colonies. It is no coincidence that Thomas Paine titled his revolutionary pamphlet series The American Crisis (1776-1783), bolstering the morale of the American colonists in "times that try men's souls" (91). Neither is it a coincidence that at the very moment of the political declaration of independence, in which the crisis of colonial legitimacy was performatively resolved (Derrida 1986), the sign of the pirate was externalized by the claim that the British monarch was a pirate, thus lending America the natural right to independence. Historical romances in early American literature, such as James Fenimore Cooper's The Red Rover (1827), used romantic/Byronic piracy to narrate the legitimacy of the revolution, appropriating the pirate as a foundational figure and an ideal type of patriotic outlaw masculinity, suffering a tragic end for a just cause. Even in narrating the crisis in gender relations, as revolutionary femininities first gave way to Republican motherhood and then to the "cult of true womanhood" (Welter) in the course of the nineteenth century, revolutionary pirates were prominent figures in popular literary production geared toward a broader and increasingly female readership, as in Lieutenant Murray's (i.e., Maturin Murray Ballou's) Fanny Campbell (1844). Former revolutionary heroines (here in the form of a patriotic female pirate) were domesticated in 
such historical romances and novelettes to make palpable the ongoing transition to a more conservative nineteenth-century femininity. Nevertheless, the text at the same time betrays a discourse of nostalgia for an earlier, revolutionary version of womanhood, disturbing any smooth transition from pirate to "angel of the house." Read side by side, these historical fictions perform similar cultural work in legitimizing America's revolutionary past and imperial future for different audiences.

The first foreign policy crisis with which the young Republic was confronted was the war with the so-called Barbary pirates at the beginning of the nineteenth century. Here, again, the delegitimizing rhetoric of Othering foreign agents - in this case, an Oriental(ized) Other-by calling them pirates was prominent in popular narratives. Captivity narratives about the experience of abduction and enslavement by Muslim 'pirates'-like Royall Tyler's Algerine Captive (1824)—redirected piracy from North Africa to North America, thus questioning the legitimacy of slavery in the United States, taking up the conjuncture of piracy and slavery that had been voiced in the Declaration of Independence and preparing the grounds for nineteenth-century abolitionist discourses. During the crisis over slavery in the nineteenth century, piracy signified the criticality of legitimacy in the context of a Black Atlantic literature (Gilroy 1993), exemplified by Trinidadian M. Maxwell Philip's littleexplored novel Emmanuel Appadocca (1854) and Herman Melville's canonical novella "Benito Cereno" (1855/1856), both of which I explore in my third chapter. While Philip explores piracy as a plot of revenge, Melville reflects on the slavery crisis as fundamentally a crisis of knowing and telling, voicing ontological insecurity as masters and slaves become indistinguishable once the tale introduces the suspicion of piracy. The conjuncture of piracy and slavery is also used (in a different context) in popular anti-Southern discourses during the Civil War, the major domestic crisis of the nineteenth century. Decorated Union letter envelopes depicted Jefferson Davis and the seceded South as prototypical pirates, stealing Africans and betraying the United States by means of a Secession thus delegitimized. These envelopes also epitomize the shift toward the visual in representations of piracy beginning in post-Civil War America.

Though the focus of my readings is on the literary representation of piracy, constructions of the pirate figure in public discourse and visual 
culture are included in this study as images of pirates frequently interacted with the written word, especially in popular texts. The figure of the pirate as well as the symbols associated with her/him, such as the Jolly Roger flag, have, from the day of the sixteenth- and seventeenthcentury broadsides, been used to market pirate texts and to evoke certain stock associations such as violence, death, and piratical nonrecognition of nation-states and their laws, even if today they have been commodified in nearly every form of material and popular culture, from coffee mugs and soccer logos to children's toys and fashion. Rather than completely separating visual and verbal discourses of piracy during the period under scrutiny, I address their interrelatedness in cultural expressions of the pirate figure across the Atlantic. My final subchapter of analysis, examining satirical cartoons, draws special attention to the importance of visual culture for the cultural articulation and negotiation of piracy. Tapping into a vast archive that still constitutes a hidden repository of cultural expression at the onset of the Civil War, this final section also highlights the increasing importance of visual representations of piracy starting in mid-nineteenth-century print culture.

The different genres and sorts of material under discussion, spanning almost two centuries, warrant comment especially in the context of a discipline like American Studies, which is often compartmentalized into special period studies. While I certainly will not be able to delve as deeply into the details of each of the crisis scenarios that contextualize my readings as many of my specialized colleagues in colonial and early American studies or Civil War studies, I hope that the diachronic scope of this book enables a broader view with regard to a trope that itself has crossed centuries and has been adapted and changed from one decade to the next. As much as these scenarios and the corresponding pirate narratives are different from each other, they share a characteristic conjunction of maritime piracy and questions of legitimacy. The narrative and visual texts under consideration all ask their readers to investigate the nature of legitimate action, even violence, and they do so according to their own needs and means. In each chapter, I have juxtaposed canonical texts with popular and/or less wellknown material that warrants closer examination: the buccaneer narratives of the late seventeenth century, which are little known except for popular versions of Exquemelin's and Dampier's writings, and Cotton Mather's well-examined sermons in chapter 1; Cooper's classic Red Rover (though little read today) and Ballou's popular historical romance Fanny Campbell, long out of print and only recently commented upon by scholarship, 
in chapter 2; and in chapter 3, Melville's "Benito Cereno," which has received continuous critical attention since at least the 1950s, side by side with M. M. Philip's Emmanuel Appadocca, a Black Atlantic novel rediscovered in the late 1990s that is still little discussed. Placing these texts next to each other, my study demonstrates not only how the pirate figure has moved across lowbrow and highbrow genres, adapting to different generic affordances, but also highlights once more the artificiality of these categorizations. Only by paying attention to such hitherto little explored archival material can we begin to understand the cultural mobility of the pirate: across oceans, genres, media, decades, and centuries, continuing with the new media of the twentieth and twenty-first centuries, from silent film to computer games. Reading such material side by side creates a dialogue between diverse genres that often drew on the same source material but was rearticulated in distinct ways and consumed by different strata of readers.

However, the present book is necessarily also limited, analyzing mostly prose narratives (with the exception of the final section). Though in the same two-hundred-year span, various other genres also engaged with and thrived on pirates and piracy-from the early modern ballad to the antebellum popular stage-I focus on prose narratives for two reasons: first, the pirate emerged as a popular figure together with the early modern development of the travel narrative and the adventure story, which led to the creation of the novel in the eighteenth century. Hence a diachronic perspective is best possible by focusing on a genre that dealt with pirates continuously for two centuries (and more). Second, I am most interested in how cultural narratives about legitimacy (with regard to the law, to maritime theft, to violence, to slavery and revolution) were constructed continuously through the figure of the pirate from the colonial era to the War of Secession. How Atlantic and later American populations told, wrote, and read stories about pirates brings to the fore prevalent anxieties with regard to shifting norms and understandings of legitimacy in conjunction with categorical differences of race, class, gender, and nation, and shows us how such anxieties were resolved in literature.

In times of collectively perceived crisis, clear-cut categories of cultural difference tend to become unhinged despite increased efforts to affirm boundaries between self and Other. While the outcome of categorical crises either reaffirms and renews or redefines and changes these boundaries, the very fact that these boundaries are discussed intensely hints at cultural and/or political anxieties and insecurities that put established 
categories of difference into doubt. Accordingly, pirate narratives could both question or cement cultural difference; yet reading them against the grain, the texts under consideration, informed by the crisis discourses prevalent at the time of their publication, defy any kind of dichotomous difference construction as they present multiple perspectives on piracy. They are characterized by polyphony, dissonance, and textual ambiguity, terms related to the concepts of dialogism and heteroglossia (as they are etched out by Mikhail Bakhtin in his theorizations of the novel ([1929] 1984 and [1934-1935] 1984). ${ }^{10}$ The main mode of analysis I employ in this study is that of contrapuntal reading, a method of (post-)colonial discourse analysis proposed by Edward Said in Culture and Imperialism (1993) which brings to the fore heteroglossia, voices hidden and suppressed by the main narrative and the textual consolidation of crisis for the sake of an optimistic portrayal of colonialism or patriotism. As a practice of deconstructive reading (rather than "a statement about the actual structure of colonial texts" [Mackenthun 2006, 12]), contrapuntal analysis shows "a simultaneous awareness both of the metropolitan history that is narrated and of those other histories against which (and together with which) the dominating discourse acts" (Said 1993, 59).

Said's analyses mostly refer to the canonical prose writing of the British Empire in its heyday in the nineteenth century, a fact that has often been criticized as Occidentalist or aesthetically elitist and conservative (Clark 1999, 6; Mackenthun 2004, 35). Further points of criticism relate to the notion of counterpoint itself, derived from Western classical music (Bach, Schoenberg, Glenn Gould), which assumes a basic unity in a piece of music in which point and counterpoint act together rather than against each other. Also, Said's under-theorization of the process and method of contrapuntal reading and his arguably much too schematic idea of oppositionality have been criticized (Kennedy 2000, 107, 110). While Said's reconciliatory assumption of an ultimately harmonious text is indeed problematic, also with regard to his literary analyses (Mackenthun 2004, 332 n. 2), the notion of the counterpoint nevertheless remains useful in its metaphorical quality, emphasizing the importance of submerged, dissonant voices that run counter to the main narrative within a cultural text. I retain the concept despite its problems because it enables readings of non-canonized texts whose polyphonic qualities have been rarely addressed. Following Mackenthun's arguments in her examination of Said's concept and its adaptability to the study of the oceanic context of antebellum American literature, the notion of counterpoint 
insinuates that aesthetic complexity in (post-) colonial texts is a result of their "difficult mobility' between the metropolitan center and the colonial periphery" $(2004,335 ; 2006)$. Contrapuntal reading presupposes the placement of imperial/colonial texts into a framework no longer limited by imperial and national borders. As Said argues, referring to Gramsci's notion of hegemony:

Western cultural forms can be taken out of the autonomous enclosures in which they have been protected, and placed instead in the dynamic global environment created by imperialism, itself revised as an ongoing contest between north and south, metropolis and periphery, white and native. We may thus consider imperialism as a process occurring as part of the metropolitan culture, which at times acknowledges, at other times obscures the sustained business of the empire itself. The important point ... is how the national ... cultures maintained hegemony over the peripheries. How within them was consent gained and continuously consolidated for the distant rule of native peoples and territories? $(1993,58)$

Contrapuntal reading hence constitutes a form of "reading back" (Do Mar Castro Varela and Dhawan 2005, 52), a reading from the perspective of the colonized in order to unveil the presence of the "coloniality of power" (Walter Mignolo quoting Anibal Quijano 2000, 16), the "system that organized the distribution of epistemic, moral, and aesthetic resources in a way that both reflects and reproduces empire" (Alcoff 2007,83 ) inscribed in cultural expression, both on the level of representation and epistemology. ${ }^{11}$ It allows for a point of view between imperial narrative and postcolonial perspective and constructs a counter-narrative in the act of reading, which time and again pierces through the surface of single texts: Kennedy calls Said's model a "dual approach to literary texts" $(2000,106)$ grounded in an epistemological critique of nationalism and Western humanism that rests on his understanding of cultural expression in the colonial context as hybrid. ${ }^{12}$ For Said, the main point is to disclose the pervasiveness of imperial power in writing on the one hand and to highlight anti-imperial resistance on the other, as these resistant energies, following a Derridean, poststructural conception of textuality, can never be brought to silence but retain a spectral presence in the text. ${ }^{13}$

The method of contrapuntal reading reverberates with similar analytical approaches to identify the fraught interrelationship between European cultures and transatlantic colonialism, including slavery and the slave trade, as they have been employed by scholars like Peter Hulme (1986) or, 
in the context of African American Studies, Toni Morrison (who speaks of an absent "Africanist presence" in American literature, 1992). My critical analyses draw on all of these approaches, their main point being to disclose the pervasiveness of white western/imperial power in these texts on the one hand and to make transparent anti-imperial resistance on the other (Kennedy 2000, 106). Following a poststructural conception of textuality, such resistant energies can never be brought to silence but remain a disturbing presence in the text. They evoke, indeed, a much more general crisis at the heart of language-based cultural production: the continuing crisis of the sign. Pirate narratives, emphasizing shifting identities and ambivalent characters and plotlines, can be viewed as emblematic of such a logocentric-epistemological crisis, resulting, from a postcolonial perspective, from the criticality of legitimacy (of colonialism, of struggles for independence, of slavery) produced by the 'discovery' of the New World.

My study chimes in with a number of concerns that are currently voiced in the context of American literary and cultural studies scholarship, examining the cultural work of Anglophone American-Atlantic narratives of piracy that have been discussed so far mostly in single articles and book chapters. American Studies has turned to the sea for more than two decades: taking up earlier work like Thomas Philbrick's James Fenimore Cooper and the Development of American Sea Fiction (1961), Paul Gilroy (The Black Atlantic: Modernity and Double Consciousness, 1993), Cesare Casarino (Modernity at Sea: Melville, Marx, Conrad in Crisis, 2002), Gesa Mackenthun (Fictions of the Black Atlantic in American Foundational Literature, 2004), Paul Gilje (Liberty on the Waterfront: American Maritime Culture in the Age of Revolution, 2004), Robin Miskolcze (Women and Children First: Nineteenth-Century Sea Narratives and American Identity, 2007), Margaret Cohen (The Novel and the Sea, 2008), or Hester Blum (The View from the Masthead: Maritime Imagination and Antebellum American Sea Narratives, 2008), to name but a few, have rewritten American literary history, advancing the maritime imagination as a fundamental, yet neglected aspect of American culture. ${ }^{14}$ Reverberating with Henry Nash Smith's diagnosis that the American economic and military frontier, up to the mid-nineteenth century, was primarily imagined as maritime $([1950] 2009,12)$ as well as with the fact that the Middle Passage was constitutive of race relations in the Americas, these studies turn away from a predominantly territorial conception of American culture. Regarding the turn to the sea and the ubiquity of 
pirates in Atlantic American popular culture from the seventeenth century to the present, piracy has received renewed interest in literary and cultural studies. Since pirate narratives have often staged cultural encounters with regions inaccessible to the general reading public in the metropoles of Europe and North America, they are significant also in their repercussions for incipient inter-American and Orientalist discourses. Thus my book suggests that pirate narratives are valuable for colonial, early American, and antebellum literature and culture studies, debating, for instance, the legitimacy of the American Revolution or of the slave system in the context of Atlantic European empire-building and American expansion, and using moral and religious as well as racial and gendered discourses for this purpose.

In addition, I hope to contribute to popular culture studies that have, since the 1990s, begun to explore past popular cultural figures, forms, and texts, such as broadsides and ballads, pamphlets, and cheaply sold historical romances or dime novels. ${ }^{15}$ In the context of a genealogy of popular culture in America, the pirate has always been an important figure of mass appeal. His/Her popularity was essential for appealing to a non-elite audience to whom normative concepts of nation and empire, femininity and masculinity as well as race also needed to be brokered. These readers, of course, developed their own ways of appropriation, one of them being the pirate's heroization-whitewashing the ethnically hybrid figure along with the translation of "a revolutionary multiracial mob into storybook (white) American heroes" in early American literature, as Cathy Davidson suggests $(2004,23)$.

Last but not least, since the threat of piracy-its instability and unreliability as a legal category and its implications of violence and uncontrollability-has always met a need to be negotiated in popular symbolic economies, I am proposing to read pirate narratives as fictions of legitimation in the context of the interdisciplinary field of Law and Literature. Historian Lauren Benton (2010) reconceptualizes early modern pirates as oceanic lawyers who knew the ropes of many legal loopholes and ruses to remain within "the precarious membrane of the law" (qua Burgess 2014, $5)^{16}$; she describes such piratical agency as an expression of "vectors of law thrusting into ocean space" (Benton 2010, 112), transporting legal norms across colonial spaces-not without calling these very norms into question. Pirate narratives make visible contextualized ideologies of law (McGillivray 1994, v), and their main function can be seen in creating what Martin Kayman terms "communal narratives of justice" $(2002,16)$. 
As cultural texts of "jurisgenesis," they are concerned with the creation of a normative universe, "a world of right and wrong, of lawful and unlawful, of valid and void" (Cover 1992, 95), and, in the context of negotiating normativity, with race, class, and gender constructions informing this creation.

\section{Notes}

1. I am using the term ambivalence not merely as referring to the static opposition of conflicting signs, but rather as highlighting constantly shifting dynamics of signification (see Weber 1987, 148).

2. In a comment on this anecdote, Schillings argues that the binary opposition between civilization and maritime wilderness enacted in the definition of piracy is linked to the general construction of " civilizational" legitimacy" $(2011,301)$.

3 . On the problem of the United States as a postcolonial nation, see Buell (1992) and Mackenthun (2000).

4. As a case in point, Mark Hanna argues that the War on Piracy (17161726), for instance, was "waged just as much in the rapidly expanding print media on both sides of the Atlantic" $(2015,372)$.

5. In this context, cf. Agamben's understanding of the floating signifier as corresponding to the state of exception "in which the norm is in force without being applied" $(2005,37)$.

6 . For an overview of legal definitions of piracy, its political significance, and its repression between 1450 and 1850, see Pérotin-Dumon, who also offers a brief "sociology of piracy" (1991, 197).

7. Peggy Kamuf argues that fiction itself functions like a ship: "Between boarding a ship at sea and stepping into the 'unreal' of a fiction the difference is unremarkable, especially when fiction takes as its invented locale the very enchantment of this bordered space that emerges from the surrounding blankness [of the ocean], ... always on the verge of sinking again into the formless, figureless blankness, the sea of white ink" (1997, 201).

8. For theoretical approaches to crisis from a social science perspective, see e.g., Japp (1975).

9. On the concept of transdifference, see Lösch (2005) and Breinig and Lösch (2002), also Ganser (2008, 25-30).

10. See his "Discourse and the Novel" (1934-1935) and Problems of Dostoyevski's Poetics (1929). While I am drawing on Bakhtin when I use these terms, I believe that polyphony is a crucial characteristic in narratives of colonial contact in the Americas even prior to the emergence of the novel in the eighteenth century. The narratives under scrutiny here 
can be seen as important forebears to the novel. Yet Bakhtin's suggestion of authorial control over multiple discursive voices is unconvincing, given the more complicated notion of text(uality) in the later twentieth and twenty-first centuries. On the role of cultural contact in the Americas in the development of the novel, see Spengemann (1994).

11. For a lucid summary and critique of Mignolo's concept and his overall project of a decolonial epistemology, see Alcoff (2007). Mignolo uses the notion of the coloniality of power throughout Local Histories/Global Designs: Coloniality, Subaltern Knowledge, and Border Thinking (2000).

12. Bakhtin's distinction between intentional and organic hybridity (or heteroglossia), which Mackenthun finds important in order to differentiate between colonial texts that have unconscious contrapuntal qualities and those that intentionally employ semantic conflict at the level of historical reflection (2004), is of course problematic from a poststructural perspective on texts (which has complicated, if not abandoned, intentionality as a category for analysis).

13. In fact, Derrida's notion of deconstruction rests upon a "crisis" of the sign: "the instance of krinein or of krisis (decision, choice, judgement, discernment) is itself ... one of the essential 'themes' or 'objects' of deconstruction" (1991, 273; Kayman 2002, 16).

14. Also worth mentioning are collections of essays on this topic such as America and the Sea: A Literary History (1995, ed. Haskell Springer), The Sea and the American Imagination (2004, ed. Klaus Benesch, JonK. Adams, and Kerstin Schmidt) or "The Sea Is History": Exploring the Atlantic (2009, ed. Carmen Birkle and Nicole Waller).

15. For influential monographs in this field, see Ashby (2012), D. Cohen (1993), Cullen (1995), Leventman (2006), Neuburg (1983), and Streeby (2002).

16. For the colonial era, Burgess even suggests that "the fissure between Crown and colonial law on piracy is so profound ... that it goes beyond negotiation and argues instead for the germination of a completely separate Atlantic legal identity" (2014, 227).

\section{Works Cited}

\section{Primary Sources}

Melville, Herman. (1855-1856) 2002. "Benito Cereno." In Melville's Short Novels, edited by Dan McCall, 34-102. New York: W. W. Norton.

Murray, Lieutenant [Maturin Murray Ballou, pseud.]. 1844. Fanny Campbell: Or the Female Pirate Captain. A Tale of the Revolution. New York: Samuel French. 
Philip, Michel Maxwell. (1854) 1997. Emmanuel Appadocca; or, Blighted Life: A Tale of the Boucaneers. Edited by Selwyn R. Cudjoe. Amherst: University of Massachusetts Press.

\section{SECONDARY SOURCES}

Agamben, Giorgio. 1998. Homo Sacer: Sovereign Power and Bare Life. Translated by Daniel Heller-Roazen. Stanford: Stanford University Press.

- 2005. State of Exception. Translated by Kevin Attell. Chicago: University of Chicago Press.

Alcoff, Linda Martín. 2007. "Mignolo's Epistemology of Coloniality." The New Centennial Review 7 (3): 79-101.

Ashby, LeRoy. 2012. With Amusement for All: A History of American Popular Culture Since 1830. Lexington: University of Kentucky Press.

Bakhtin, Mikhail M. (1929) 1984. Problems of Dostoyevski's Poetics. Edited and Translated by Caryl Emerson. Minneapolis: University of Minnesota Press.

—. (1934-1935) 1984. "Discourse and the Novel." In The Dialogic Imagination: Four Essays, edited by Michael Holquist, translated by Caryl Emerson and M. Holquist, 259-422. Austin: University of Texas Press.

Beasley-Murray, Jon. 2005. "The Common Enemy: Tyrants and Pirates." South Atlantic Quarterly 104 (2): 217-225.

Benton, Lauren. 2010. A Search for Sovereignty: Law and Geography in European Empires, 1400-1900. Cambridge: Cambridge University Press.

Blum, Hester. 2008. The View from the Masthead: Maritime Imagination and Antebellum American Sea Narratives. Chapel Hill: University of North Carolina Press.

Breinig, Helmbrecht, and Klaus Lösch. 2002. "Introduction: Difference and Transdifference." In Multiculturalism in Contemporary Societies: Perspectives on Difference and Transdifference, edited by Helmbrecht Breinig, Jürgen Gebhardt, and Klaus Lösch, 11-36. Erlangen: Universitätsbund ErlangenNuremberg.

Buell, Lawrence. 1992. "American Literary Emergence as a Postcolonial Phenomenon." American Literary History 4 (3): 411-442.

Burgess, Douglas R. Jr. 2014. The Politics of Piracy: Crime and Civil Disobedience in Colonial America. Lebanon: ForeEdge/University Press of New England.

Clark, Steve. 1999. "Introduction." In Travel Writing and Empire: Postcolonial Theory in Transit, edited by Steve Clark, 1-25. London: Zed Books.

Cohen, Daniel A. 1993. Pillars of Salt, Monuments of Grace: New England Crime Literature and the Origins of American Popular Culture, 1674-1860. Amherst: University of Massachusetts Press. 
Cover, Robert. 1992. "Nomos and Narrative (1983)." In Narrative, Violence, and the Law: The Essays of Robert Cover, edited by Martha Minow, Michael Ryan, and Austin Sarat, 95-172. Ann Arbor: University of Michigan Press.

Creighton, Margaret S., and Lisa Norling, eds. 1996. Iron Men, Wooden Women: Gender and Seafaring in the Atlantic World, 1700-1920. Baltimore: Johns Hopkins University Press.

Cresswell, Tim. 2006. On the Move: Mobility in the Modern Western World. New York: Routledge.

Cullen, Jim. 1995. The Civil War in Popular Culture: A Reusable Past. Washington: Smithsonian Institution Press.

Davidson, Cathy N. 2004. Revolution and the Word: The Rise of the Novel in America. Exp. ed. New York: Oxford University Press.

Davis, Helen. 2004. Understanding Stuart Hall. London: Sage.

Derrida, Jacques. 1986. "Declarations of Independence." Translated by Tom Keenan and Tom Pepper. New Political Science 7 (1): 7-13.

- 1991. "Letter to a Japanese Friend (1987)." In A Derrida Reader: Between the Blinds, edited by Peggy Kamuf, 269-276. New York: Harvester Wheatsheaf.

Do Mar Castro Varela, María, and Nikita Dhawan. 2005. Postkoloniale Theorie: Eine kritische Einführung. Bielefeld: transcript.

Fenske, Uta, Walburga Hülk, and Gregor Schuhen, eds. 2017. Die Krise als Erzäblung: Transdisziplinäre Perspektiven auf ein Narrativ der Moderne. Bielefeld: transcript.

Foucault, Michel. 1986. "Of Other Spaces." Translated by Jay Miskowiec. Diacritics 1: 22-27.

Ganser, Alexandra. 2008. Roads of Her Own: Gendered Space and Mobility in American Women's Road Narratives, 1970-2000. Amsterdam: Rodopi.

Gilje, Paul A. 2004. Liberty on the Waterfront: American Maritime Culture in the Age of Revolution. Philadelphia: University of Pennsylvania Press.

Gilroy, Paul. 1993. The Black Atlantic: Modernity and Double Consciousness. London: Verso.

Grunwald, Henning, and Manfred Pfister. 2007. "Krisis! Krisenszenarien, Diagnosen und Diskursstrategien." In Krisis! Krisenszenarien, Diagnosen, Diskursstrategien, edited by Henning Grunwald and Manfred Pfister, 7-20. München: Wilhelm Fink.

Hanna, Mark G. 2015. Pirate Nests and the Rise of the British Empire, 15701740. Chapel Hill: University of North Carolina Press.

Heller-Roazen, Daniel. 2009. The Enemy of All: Piracy and the Law of Nations. New York: Zone Books.

Hulme, Peter. 1986. Colonial Encounters: Europe and the Native Caribbean 1492-1797. London: Routledge. 
Japp, Klaus Peter. 1975. Krisentheorien und Konfliktpotentiale. Frankfurt am Main: Campus.

Jones, Steve. 2006. Antonio Gramsci. London: Routledge.

Kahn, Victoria. 2002. "Early Modern Rights Talk." In Law and Literature, edited by Brook Thomas. Special issue, REAL 18: 65-85.

Kamuf, Peggy. 1997. The Division of Literature or the University in Deconstruction. Chicago: University of Chicago Press.

Kayman, Martin A. 2002. "Law-and-Literature: Questions of Jurisdiction." Law and Literature, edited by Brook Thomas. Special issue, REAL 18: 1-20.

Kempe, Michael. 2008. "Seeraub als Broterwerb: Bewaffnete Auseinandersetzungen zwischen Freibeutern und Kauffahrern aus völkerrechtlicher Perspektive." In Seelente und Leben an Bord im Ersten Kolonialzeitalter (15.18. Jahrhundert), edited by Eberhard Schmidt, 387-412. Dokumente zur Geschichte der europäischen Expansion 7. Wiesbaden: Harrassowitz.

- 2010. Fluch der Weltmeere. Piraterie, Völkerrecht und internationale Beziehungen, 1500-1900. Frankfurt am Main: Campus.

Kennedy, Valerie. 2000. Edward Said: A Critical Introduction. Cambridge: Polity Press.

Koselleck, Reinhart. 1978. "Krise." In Geschichtliche Grundbegriffe: Historisches Lexikon zur Politisch-Sozialen Sprache in Deutschland. Vol. 3, edited by Otto Brunner and Werner Conze, 617-650. Stuttgart: Klett-Cotta.

Leventman, Seymour. 2006. American Popular Culture: Historical and Pedagogical Perspectives. Newcastle: Cambridge Scholars Press.

Lösch, Klaus. 2005. "Begriff und Phänomen der Transdifferenz: Zur Infragestellung binärer Differenzkonstrukte." In Differenzen anders denken: Bausteinie $z u$ einer Kulturtheorie der Transdifferenz, edited by Lars Alliolio-Näcke, Brita Kalscheuer, and Arne Manzeschke, 26-49. Frankfurt am Main: Campus.

Mackenthun, Gesa. 2000. "America's Troubled Postcoloniality: Some Reflections from Abroad.” Discourse 22 (3): 34-45.

- 2004. "The Literary Presence of Atlantic Colonialism as Notation and Counterpoint." ZAA 52 (4): 331-349.

. 2006. "'Between Worlds': Edward Said and the Rediscovery of Empire in American Studies." In America and the Orient, edited by Heike Schaefer, 1-20. Heidelberg: Winter.

McGillivray, Anne. 1994. "'Recherche Sublime': An Introduction to Law and Literature." Mosaic 27 (4): i-ix.

Mignolo, Walter D. 2000. Local Histories, Global Designs: Coloniality, Subaltern Knowledges, and Border Thinking. Princeton: Princeton University Press.

Miskolcze, Robin. 2007. Women and Children First: Nineteenth-Century Sea Narratives and American Identity. Lincoln: University of Nebraska Press.

Morrison, Toni. 1992. Playing in the Dark: Whiteness and the Literary Imagination. Cambridge: Harvard University Press. 
Neuburg, Victor E. 1983. The Popular Press Companion to Popular Literature. Bowling Green: Bowling Green State University Popular Press.

Nünning, Ansgar. 2007. "Grundzüge einer Narratologie der Krise: Wie aus einer Situation ein Plot und eine Krise (konstruiert) werden." In Krisis! Krisenszenarien, Diagnosen, Diskursstrategien, edited by Henning Grunwald and Manfred Pfister, 48-71. Munich: Wilhelm Fink.

- 2009. "Steps Towards a Metaphorology (and Narratology) of Crises: On the Functions of Metaphors as Figurative Knowledge and Mininarrations." In Metaphors Shaping Culture and Theory, edited by Herbert Grabes, Ansgar Nünning and Sibylle Baumbach. Special issue, REAL 25: 229-262.

Pérotin-Dumon, Anne. 1991. "The Pirate and the Emperor: Power and the Law on the Seas, 1450-1850." In The Political Economy of Merchant Empires, edited by James D. Tracy, 196-227. Cambridge: Cambridge University Press.

Philbrick, Thomas. 1961. James Fenimore Cooper and the Development of American Sea Fiction. Cambridge: Harvard University Press.

Poier, Salvatore. 2009. "Hostis Humani Generis: History of a MultiFaceted Word." In Pirates and Piracy, edited by Andrew Opitz. Special issue, Darkmatter 5. http://www.darkmatter101.org/site/2009/12/20/hos tis-humani-generis-history-of-a-multi-faceted-word.

Rediker, Marcus. 2004. Villains of All Nations: Atlantic Pirates in the Golden Age. Boston: Beacon Press.

Rennie, Neil. 2013. Treasure Neverland: Real and Imaginary Pirates. Oxford: Oxford University Press.

Said, Edward W. (1993) 1994. Culture and Imperialism. London: Vintage.

Schillings, Sonja. 2011. "The Concept of Hostis Humani Generis in Cultural Translation: Somali Piracy, Discursive Containment, and the Creation of Extralegal Spaces." In States of Emergency-States of Crisis, edited by Winfried Fluck, Katharina Motyl, Donald E. Pease, and Christoph Raetzsch. Special issue, REAL 27: 295313.

- 2015. "The Privateering Critic: Re-Reading the Problem of the Ban in Marie de France and Giorgio Agamben." Krisis: Journal for Contemporary Philosophy 1: 30-38.

- 2017. Enemies of All Humankind: Fictions of Legitimate Violence. Hanover: Dartmouth College Press.

Shields, David S. 1990. Oracles of Empire: Poetry, Politics, and Commerce in British America, 1690-1750. Chicago: University of Chicago Press.

Smith, Henry Nash. (1950) 2009. Virgin Land: The American West as Symbol and Myth. Cambridge: Harvard University Press.

Spengemann, William C. 1994. A New World of Words: Redefining Early American Literature. New Haven: Yale University Press.

Streeby, Shelly. 2002. American Sensations: Class, Empire, and the Production of Popular Culture. Berkeley: University of California Press. 
Thomson, Janice E. 1994. Mercenaries, Pirates, and Sovereigns: State-Building and Extraterritorial Violence in Early Modern Europe. Princeton: Princeton University Press.

Tompkins, Jane. 1985. Sensational Designs: The Cultural Work of American Fiction, 1790-1860. Oxford: Oxford University Press.

Weber, Samuel. 1987. Institution and Interpretation. Minneapolis: University of Minnesota Press.

Open Access This chapter is licensed under the terms of the Creative Commons Attribution 4.0 International License (http://creativecommons.org/licenses/ by $/ 4.0 /)$, which permits use, sharing, adaptation, distribution and reproduction in any medium or format, as long as you give appropriate credit to the original author(s) and the source, provide a link to the Creative Commons license and indicate if changes were made.

The images or other third party material in this chapter are included in the chapter's Creative Commons license, unless indicated otherwise in a credit line to the material. If material is not included in the chapter's Creative Commons license and your intended use is not permitted by statutory regulation or exceeds the permitted use, you will need to obtain permission directly from the copyright holder.

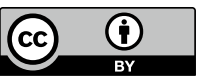

